\title{
A novel retrieval system for nearly complete microbial genomic fragments from soil samples
}

\author{
Wen-Han Yu, Shiun-Cheng Su, Chia-Yin Lee* \\ Graduate Institute of Agricultural Chemistry, National Taiwan University, Taipei 10617, Taiwan
}

Received 28 September 2007; received in revised form 29 November 2007; accepted 29 November 2007

Available online 8 December 2007

\begin{abstract}
The construction of a complex genomic library is one of the comprehensive ways to study a complex bacterial community and to access the variety of metabolic pathways present in the rich soil environment. In this report, we developed a new protocol whereby we are able to retrieve nearly complete microbe genomic fragments from soil samples, which are employed to generate a metagenomic library for visualizing the basic scaffolding of the soil microbial community. The use of direct cell lysis within soil-embedded agarose plugs, along with a double-size selection, enabled us to successfully isolate pure and high-molecular weight DNA $(0.1-1 \mathrm{Mb})$ without the need for any further purification. A metagenomic library containing $1.2 \mathrm{Gbp}$ of DNA in total was constructed. Furthermore, analysis of the microbial community structure using $16 \mathrm{~S}$ rDNA partial sequences found the dominant phylotypes to consist of $\alpha$-Proteobacteria and Actinobacteria, which are similar to those seen in forest and agricultural soils, and numerous uncultured microbes from a wide variety of bacterial taxa as well. In conclusion, this study presents a novel protocol for generating a metagenomic library that carries much larger and diverse DNA fragments from soil bacteria that will be applied for the reconstruction of soil microbial genomes and the discovery of novel habitat-specific pathways.
\end{abstract}

(C) 2007 Elsevier B.V. All rights reserved.

Keywords: Metagenomic library; Microbial community structure

\section{Introduction}

Sequence data from microorganisms provide scientists with a blueprint for rapidly assessing organism-specific pathways and microbial network regulation on the basis of comparative genomics. According to previous studies, the sequenced microbial genomes only present a small piece of information of total microbiota in the environment (Torsvik and Ovreas, 2002). Therefore, the construction of metagenomic libraries via the direct cloning of genomic fragments isolated from soil samples has become an essential step in retrieving the collective genomes of environmental microflora, as opposed to traditional genome sequencing projects that required the isolation of a single species from laboratory cultivation. However, the complexity and heterogeneity of the biotic and abiotic

\footnotetext{
* Corresponding author. Mailing address: Graduate Institute of Agricultural Chemistry, National Taiwan University, No.1, Sec. 4, Roosevelt Rd., Taipei 10617, Taiwan. Tel.: +8862 33664812; fax: +886223660581.

E-mail address: clee@ntu.edu.tw (C.-Y. Lee).
}

components of soil are the largest obstacles for building a well-organized soil-based library (Rondon et al., 2000; Daniel, 2005).

Separating whole DNA from the soil mixtures is first challenge to overcome before construction of a highly representative library. Many investigators have attempted to optimize DNA recovery from soils by implementing severe physical treatments, such as bead mill homogenization and ultrasonication to lyse the microbial cells (Steffan et al., 1988; Kuske et al., 1998). Such treatments apparently reduce the size of the DNA fragments to sizes of 5 to $10 \mathrm{~kb}$ or even less. Another two groups (Zhou et al., 1996; Krsek and Wellington, 1999) showed that a SDS-based cell lysis, in combination with grinding and freezing-thawing, resulted in higher DNA yields with sizes of about $20-40 \mathrm{~kb}$ from most gram-positive bacteria. All of these protocols have to accompany with DNA purification for eliminating humic substances which seriously inhibited the following operations, e.g. DNA cloning (Tsai and Olson, 1992). However, as those stated above, many of the steps required for cell lysis and DNA purification result in severe 
DNA shearing. To improve DNA recovery size and purity, this study focuses on the development of a new strategy by modifying the traditional genome sequencing project library protocol (Zimmer and Verrinder Gibbins, 1997; Osoegawa et al., 1998). Accordingly, we obtain high-molecular weight (HMW) DNA fragments from soil mixtures that can be used in the construction of large-insert libraries.

To date, two major methods for making soil DNA libraries exist. One utilizes large-insert cloning vectors, such as bacterial artificial chromosome (BAC) (Rondon et al., 2000), fosmids (Quaiser et al., 2002; Quaiser et al., 2003; Voget et al., 2003; Treusch et al., 2004), or cosmids (Brady et al., 2002; Courtois et al., 2003). The other involves small-insert expression-cloning, i.e. short fragments of soil DNA was cloned to expression vector for library screening (Henne et al., 1999; Majernik et al., 2001; Riesenfeld et al., 2004), or random shotgun sequencing libraries (Tyson et al., 2004; Venter et al., 2004; Tringe et al., 2005). Two research groups (Tyson et al., 2004; Venter et al., 2004), have succeeded in building a metagenome library using a shotgun approach and have reconstructed all or certain dominant microbial genomes from a very simple microbial consortia. However, this successful example only happened in this extreme simple case. Tringe and her colleagues (Tringe et al., 2005) have demonstrated that less than $1 \%$ of the nearly 150,000 reads generated from a high-diversity soil sample exhibited overlap with reads from independent shotgun library clones. Consequently, this is an immense challenge for computer sequence assembly, especially in cases where lowabundance community members and genomes with high frequency of polymorphic variations, insertions and/or deletions are present. In addition, evidence for horizontally transferred genes and genomic islands in prokaryotic genomes has become more prevalent in the last decade or so (Dobrindt et al., 2004). The presence of alien genes or fragments in the genome, which can be up to $100 \mathrm{~kb}$ in length, would seriously affect any prediction of the genetic composition when assembling the reads or sequences from a small-insert library. In contrast, largeinsert libraries raise the ratio for isolating overlapping fragments in assemblies that have extremely diverse genomes while also eliminating interference from extensive genomic rearrangements. Furthermore, paired-end sequences from each clone provide information about the orientation and scaffolding of the assembled genome fragments and how they should be linked together (Hallam et al., 2004). These larger DNA fragments also offer a more precise statistical analysis of the $G+C$ content, codon usage, and oligo-nucleotide frequencies, all of which aid in species identification and linking specific metabolisms and microbial communities together (Teeling et al., 2004; Chen and Pachter, 2005). According to the above comparisons, largeinsert library provides a batter way to acquire reliable and integral sequence information for further applications.

Here, we described a new extraction system that successfully overcame the most challenging issue, i.e., separation of genetic materials from the complex biotic and abiotic components present in orchard soil in Taiwan, and is capable of deriving high-purity and diverse HMW DNA $(0.1-1 \mathrm{Mb})$. Using this DNA, we then constructed a metagenome BAC library whose average size was about $90 \mathrm{kbp}$ and subsequently surveyed the phylogenetic distribution among the library. The reservoir containing HMW DNA fragments will be employed to elucidate the habitat-specific metabolisms represented within the soil samples as well as the genes involved in the generation of novel natural products.

\section{Materials and methods}

\subsection{Bacteria strains and plasmids}

E. coli strain TransforMax ${ }^{\mathrm{TM}} \mathrm{EC} 300^{\mathrm{TM}}$ and $\mathrm{BAC}$ vector CopyControl ${ }^{\mathrm{TM}} 2 \mathrm{pCC}^{\mathrm{B}} \mathrm{BAC} \mathrm{CM}^{\mathrm{TM}}$ vector, copy number of which can be controlled by an inducer, were purchased from Epicentre (USA). Chloramphenicol (Sigma, USA) was added to all the media at a concentration of $12.5 \mu \mathrm{g} / \mathrm{ml}$.

\subsection{Soil sampling and preservation}

The soils from an orchard were collected from three places in Tainan, Taiwan. A sterile spoon was employed to collect approximately 100 -g samples from the upper 2 to $5 \mathrm{~cm}$ of the soil at each site near the roots of the trees. All of the samples were lyophilized, ground to a fine powder with a mortar and pestle, and then stored at $-20^{\circ} \mathrm{C}$.

\subsection{HMW DNA extraction from soil}

One gram of soil was mixed with $1 \mathrm{ml}$ of suspension buffer (10 mM Tris- $\mathrm{HCl}, 1 \mathrm{M} \mathrm{NaCl}, 50 \mathrm{mM}$ EDTA) and $1 \mathrm{ml}$ of $1 \%$ low-melting agarose (Fig. 1). The suspension was kept at $37-$ $40{ }^{\circ} \mathrm{C}$ to prevent the agarose from solidifying. The slurryagarose mixture was then pipetted into molds (Pharmacia). After setting at $4{ }^{\circ} \mathrm{C}$, three plugs were transferred to a 2-ml Eppendorf tube, $1.5 \mathrm{ml}$ lysis buffer $(50 \mathrm{mM}$ Tris-HCl, $100 \mathrm{mM}$ EDTA, $100 \mathrm{mM} \mathrm{NaCl}, 0.2 \%$ (w/v) sodium deoxycholate, $0.5 \%$ $(\mathrm{w} / \mathrm{v}) 20$ cetyl ether, $0.5 \%(\mathrm{w} / \mathrm{v})$ lauroylsarcosine sodium salt and $5 \mathrm{mg} / \mathrm{ml}$ lysozyme) were added and the tubes were stored at $37{ }^{\circ} \mathrm{C}$ for $24 \mathrm{~h}$ with gentle horizontal agitation $(50 \mathrm{rpm})$. The lysis buffer was then replaced with $1.5 \mathrm{ml}$ digestion buffer (100 mM Tris- $\mathrm{HCl}, 500 \mathrm{mM}$ EDTA, $100 \mathrm{mM}$ sodium phosphate, $1.5 \mathrm{M} \mathrm{NaCl}, 1.5 \mathrm{mg} / \mathrm{ml}$ protease $\mathrm{K}$ and $0.5 \%(\mathrm{w} / \mathrm{v})$ SDS) and the tubes were stored at $50{ }^{\circ} \mathrm{C}$ for $24 \mathrm{~h}$ with a gentle horizontal agitation $(50 \mathrm{rpm})$. The plugs were then collected and washed with 50 volumes of wash buffer $(10 \mathrm{mM}$ Tris- $\mathrm{HCl}[\mathrm{pH}$ 8.0], $100 \mathrm{mM}$ EDTA) and then several times with ice-cold $0.5 \times$ TBE buffer. Next, the plugs were secured against the teeth of a comb for an electrophoresis unit using several drops of melted agarose, and cooled down to $50{ }^{\circ} \mathrm{C}$. Afterwards, more agarose was poured into the tray around the plugs and allowed to solidify. The HMW DNA was separated by pulsed-field gel electrophoresis (PFGE) using a Gene Navigator system (Pharmacia) set at $175 \mathrm{~V}$, with a $1-14$-s pulse, for $18 \mathrm{~h}$ at $8{ }^{\circ} \mathrm{C}$ in $0.5 \times$ TBE buffer. DNA fragments larger than $240 \mathrm{~kb}$ were compressed into a small region at the top of the gel. This band was cut out and prepared for the second round of PFGE, which was done using a $165 \mathrm{~V}$, with a 5 -s pulse, for $16 \mathrm{~h}$ at $8{ }^{\circ} \mathrm{C}$ 


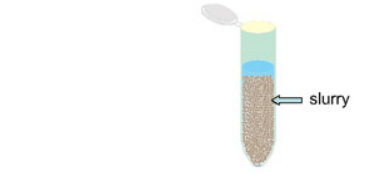

Slurry mixed with agarose and suspension buffer
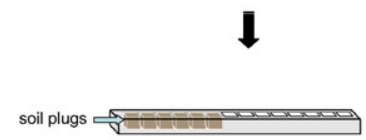

Cool down the molds to solidify the soil plugs at $4^{\circ} \mathrm{C}$

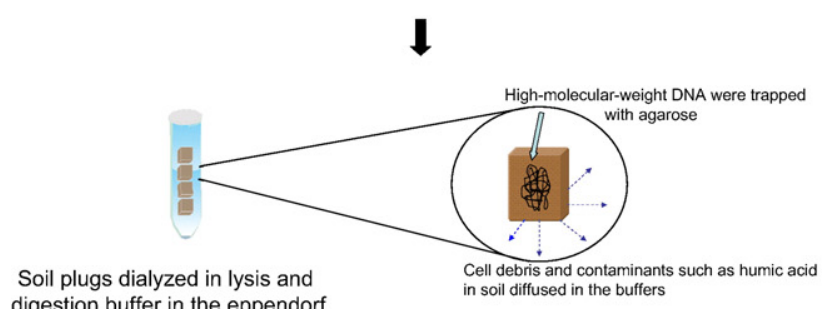

Soil plugs dialyzed in lysis and
digestion buffer in the eppendorf

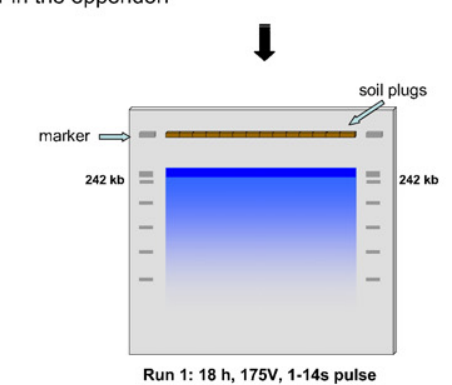

Directly embedded the plugs in the gel. Separated by PFGE and Sliced the condensed zone

\section{1}

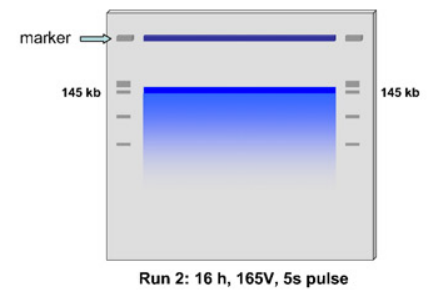

Separated the fragments by the second PFGE and Sliced the position larger than $145 \mathrm{~kb}$

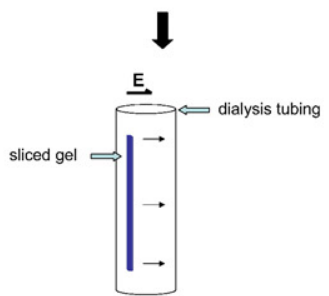

Isolated the large DNA fragments by electroelution and then precipitated in the PEG 8000 buffer

Fig. 1. Schematic showing the process to extract HMW DNA directly from soil without DNA purification. During dialysis, the soil contaminants and cell debris was removed from the soil plugs. Afterwards, PFGE separation was used to isolate high quality environmental genomic DNA.

in $0.5 \times$ TBE buffer. After staining, the HMW DNA band was excised from the gel and the DNA fragments were isolated using electroelution following the method described by Strong et al., (1997), except that the TAE buffer was replaced with $0.5 \times$ TBE buffer and the procedure was run at $120 \mathrm{~V}$ for $10 \mathrm{~h}$ at $8{ }^{\circ} \mathrm{C}$. The HMW DNA was then precipitated with $30 \%$ polyethylene glycol 8000 and $1.5 \mathrm{M} \mathrm{NaCl}$ (PGE buffer) for $30 \mathrm{~min}$ on ice. The sample was centrifuged for $20 \mathrm{~min}$ and the supernatant was removed. Finally, the DNA was dissolved in $10 \mathrm{mM}$ Tris- $\mathrm{HCl}$ (pH 8.0) buffer.

Other extraction methods were examined for comparison. The soil DNA kit used in this study was the UltraClean Soil DNA Kit from MO-BIO Laboratories. The SDS-based DNA extraction method followed that of Zhou et al. (1996), and the resulting DNA fragments were purified by Sepharose CL-4B (Pharmacia) as described by Jackson et al. (1997).

\subsection{BAC library construction}

After concentrating the HMW DNA isolated from soil samples, partial digestion was carried out with an appropriate amount of Hind III (Roche) and $1 \times$ BSA for 15 min at $37{ }^{\circ} \mathrm{C}$. Ligations were performed in $50-\mu 1$ reactions containing $65 \mathrm{ng}$ of partially digested DNA, $50 \mathrm{ng}$ of the linear and dephosphorylated pCC1BAC vector (1:10 molar ratio of insert: vector), ligase buffer and $5 \mathrm{U}$ of T4 DNA ligase (Fermentas) at $16{ }^{\circ} \mathrm{C}$ overnight. After inactivating the ligase, the ligation products were desalted and condensed by drop-dialysis using a $0.025-\mu \mathrm{m}$ membrane filter suspended on PEG buffer. Two microliters of the ligation reaction were employed to electroporate $20 \mu \mathrm{l}$ of E. coli TransforMax EC300 cells using Gene Pulser II (Bio Red). Electroporation conditions were $12.5 \mathrm{kV} /$ $\mathrm{cm}, 100 \Omega$ and $25 \mu \mathrm{F}$. After transformation, the cells were resuspended in $500 \mu \mathrm{l}$ of SOC medium and incubated for $1 \mathrm{~h}$ at $37^{\circ} \mathrm{C}$. The broth was plated on the LB agar medium containing $12.5 \mu \mathrm{g} / \mathrm{ml}$ chloramphenicol, $40 \mu \mathrm{g} / \mathrm{ml} \mathrm{X}$-gal and $0.4 \mathrm{mM} \mathrm{IPTG}$ and incubated at $37^{\circ} \mathrm{C}$ overnight. White recombinant colonies were placed into 96-well plates containing LB freezing buffer (Osoegawa et al., 1998) and stored at $-80^{\circ} \mathrm{C}$.

\subsection{Phylogenetic relationship analysis of $16 \mathrm{~S} r D N A$}

A mixed pool of recombinant plasmids was prepared from each 96-well plate. To do this, each of the clones was grown overnight in $2 \mathrm{ml} \mathrm{LB}$, with chloramphenicol added, and the plasmids from each was isolated using the protocol of Rondon et al. (1999) and mixed together. This pooled DNA was used for 16S rDNA PCR amplification with primers 530F, 1492R specifying to Bacteria and Archaea $16 \mathrm{~S}$ rDNA gene (Hugenholtz and Goebel, 2001). The library was constructed and the clones with partial 16S rDNA gene were sequenced by an ABI 377-96 DNA sequencer (Perkin-Elmer).

The nucleotide sequences of the partial 16S rDNA fragments were analyzed using the Clustal $\mathrm{X}$ program to obtain a preliminary list of the closest phylogenetic neighbors. Distance matrices and phylogenetic trees were constructed using the Jukes-Cantor algorithm and neighbor-joining. The branching consistency in the phylogenetic trees were evaluated using 100 randomly resampled data points produced by the SEQBOOT program, and finally bootstrap values were calculated using the 


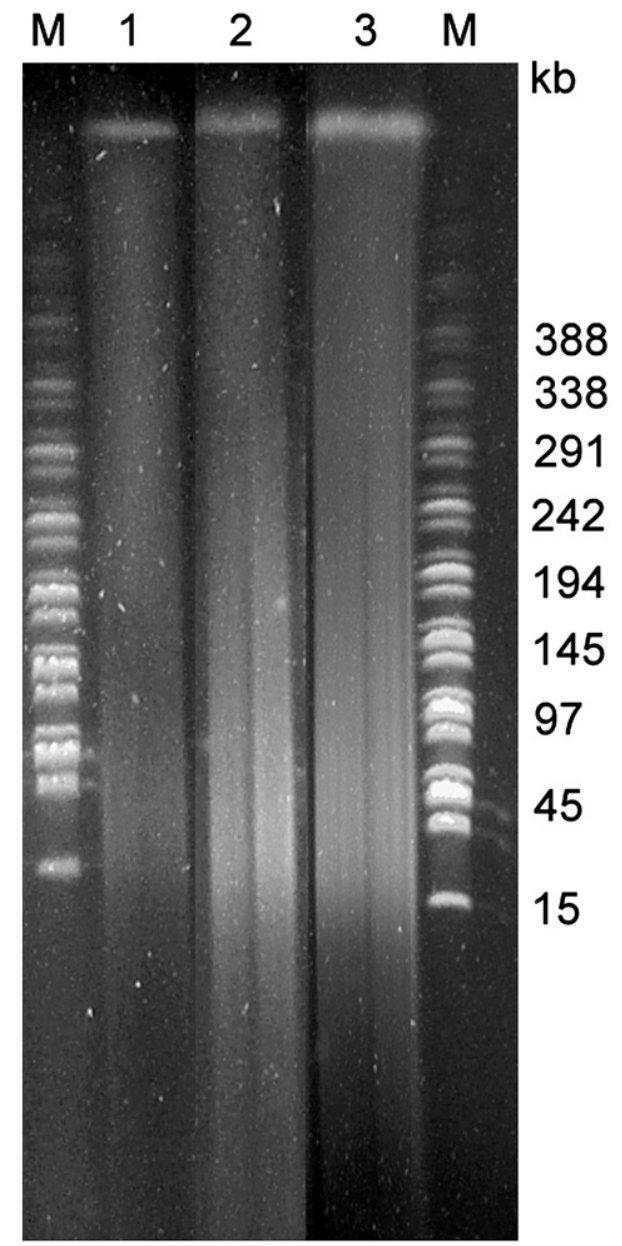

Fig. 2. Characterization of the new extraction method with different soils. DNA was isolated from: Lane 1, sandy clay loam; Lane 2, sandy loam; Lane 3, loam. Major bands were concentrated toward the top of each lane due to limitations in PFGE. The results are shown after the first round of phase gel electrophoresis. The PFGE was performed at $180 \mathrm{~V}$, with $1-25 \mathrm{~s}$ pulses, for $18 \mathrm{~h}$ at $8{ }^{\circ} \mathrm{C}$ in $0.5 \times$ TBE buffer.

CONSENSE program. The programs for phylogenetic analysis are included in the PHYLIP package (Version 3.6) and executed using the free on-line Server Interface (http://bioweb.pasteur.fr/ seqanal/phylogeny/phylip-uk.html).

All of the partial 16S rRNA sequences obtained from agricultural soil samples (3370 sequences) and forest soil samples (219 sequences) were downloaded from the NCBI website and compared with the $16 \mathrm{~S}$ rDNA library generated in this study. To accomplish this, two programs, Classifier and Library Compare, from the RDP II website were used (http:// rdp.cme.msu.edu/index.jsp).

\subsection{Sequence deposition}

The sequences of the partial rDNA clones in this paper were submitted to GenBank under the following accession number: GenBank EU151801-EU151840.

\section{Results}

\subsection{A new approach to extraction of HMW DNA from soil}

A new soil DNA extraction system (Fig. 1) was developed in this study for two major reasons: to maintain the integrity of the genomic DNA, a problem encountered by several previously reported extraction methods (Steffan et al., 1988; Zhou et al., 1996; Kuske et al., 1998; Krsek and Wellington, 1999); and to generate a sample that is highly representative of the soil microbe structure using a direct lysis method without the need to collect biomass (Krsek and Wellington, 1999; Quaiser et al., 2002; Treusch et al., 2004).

PFGE analysis of the DNA fragments purified with the new method found that the sizes ranged from $15 \mathrm{~kb}$ to more than $1000 \mathrm{~kb}$ in length (Fig. 2), demonstrating that this protocol does not seriously disrupt the genomes as they are being purified. To determine if this is true for different soils, the relationship between the DNA extraction efficiency and the type of soil was evaluated using soil samples taken from three independent sites and were roughly classified as sandy clay loam, sandy loam and loam soils (Fig. 2). Although the electrophoresis results found that the amount of DNA extracted from the sandy loam and loam soils was greater than that of the sandy clay loam, these differences could be due to the soil characteristics of the sandy clay loam, which has a much smaller pore size than the other two soil types.

\subsection{Evaluation of various DNA extraction procedures}

The new extraction system was compared with two other popular procedures commonly employed to extract soil DNA (Table 1). Method I, the soil DNA isolation kit, was very convenient and the protocol was quickly finished, but the DNA

Table 1

Comparison of three different methods used to extract DNA from agricultural soils

\begin{tabular}{|c|c|c|c|c|c|c|}
\hline \multirow[t]{2}{*}{ Method $^{\mathrm{a}}$} & \multirow[t]{2}{*}{ Time } & \multicolumn{2}{|l|}{ Purity $^{\mathrm{b}}$} & \multirow{2}{*}{$\begin{array}{l}\text { Additional } \\
\text { purification }\end{array}$} & \multirow{2}{*}{$\begin{array}{l}\text { Concentration } \\
\mu \mathrm{g} / \mathrm{g} \text { (dry weight) }\end{array}$} & \multirow{2}{*}{$\begin{array}{l}\text { Molecular } \\
\text { weight }\end{array}$} \\
\hline & & $\mathrm{A}_{260} / \mathrm{A}_{230}$ & $\mathrm{~A}_{260} / \mathrm{A}_{280}$ & & & \\
\hline I & 1 day & $1.95 \pm 0.03$ & $2.03 \pm 0.06$ & No & $9.6 \pm 1.1$ & $10-20 \mathrm{~kb}$ \\
\hline II & 2 days & $0.97 \pm 0.12$ & $1.45 \pm 0.09$ & Yes & $12.5 \pm 0.7$ & $30-50 \mathrm{~kb}$ \\
\hline III & 4 days & $1.81 \pm 0.07$ & $1.89 \pm 0.03$ & No & $19.2 \pm 1.8$ & $10-1000 \mathrm{~kb}$ \\
\hline
\end{tabular}

${ }^{a}$ Method I: UltraClean soil DNA isolation Kit (MO BIO); Method II: the method reported from Zhou et al. (1996); Method III: DNA extraction by embedding soil in agarose.

${ }^{b}$ Ratio of $\mathrm{A}_{260} / \mathrm{A}_{280}>1.7$ is indicative of pure DNA. Ratio of $\mathrm{A}_{260} / \mathrm{A}_{230}>2$ is indicative of pure DNA, whereas a low ratio is indicative of phenol (humic) contamination (Steffan et al., 1988). 


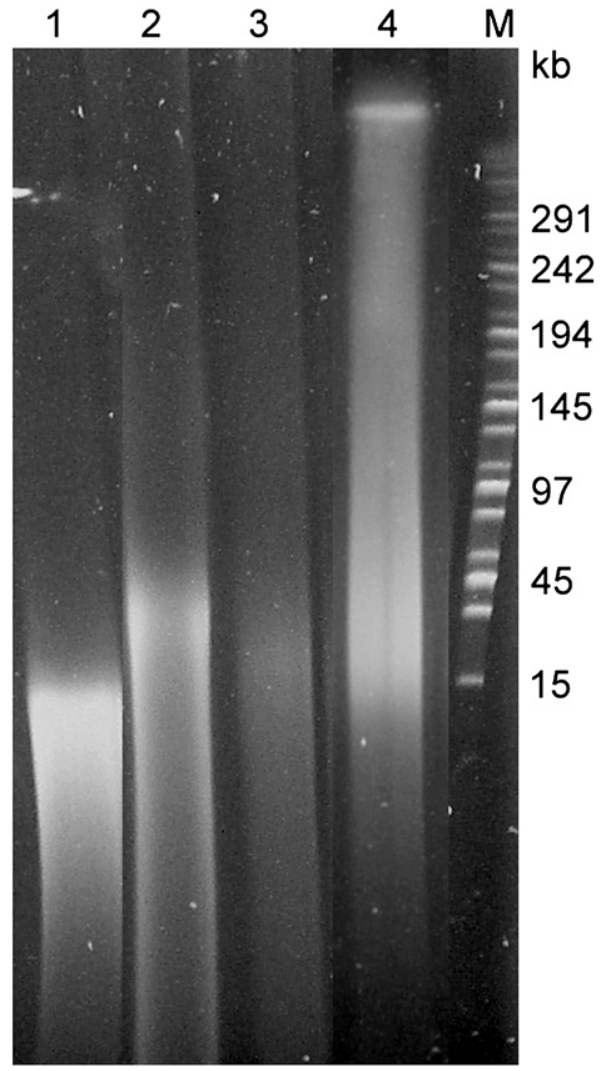

Fig. 3. Comparison with different DNA extraction methods from soil by PFGE analysis used at $180 \mathrm{~V}$, with $1-25 \mathrm{~s}$ pulses, for $18 \mathrm{~h}$ at $8{ }^{\circ} \mathrm{C}$ in $0.5 \times \mathrm{TBE}$ buffer. Lane 1, UltraClean soil DNA isolation Kit (MO BIO); Lane 2, the method reported from Zhou et al. (1996); Lane 3, DNA from the same method as Lane 2 but purified further with a spin column packing Sepharose CL-4B gel. Lane 4, DNA extracted using the method developed in this study; Lane M, MidRange PFG markers.

quality was not adequate for BAC vector cloning. Owing to bead mill homogenization employed in this kit, the genomic DNA was significantly sheared in the process (Fig. 3; Table 1). The average size of the fragments was about $10 \mathrm{~kb}$, which is too short for a large-fragment library, even though the DNA yields were approximately $10 \mu \mathrm{g}$ DNA per gram dry soil without any further purification. Method II, modified from Zhou et al. (1996), had a greater yield (12.5 $\mu \mathrm{g}$ DNA per gram dry soil) and produced larger DNA fragments (average $\sim 45 \mathrm{~kb}$ ). Unfortunately, a significant amount of humic substances were coextracted with the DNA during the organic solvent extraction step. The $\mathrm{A}_{260} / \mathrm{A}_{230}$ ratio for DNA purified using this method was $0.97 \pm 0.12$, which is significantly lower than the ratios obtained by other methods (Table 1). Furthermore, both the size and concentration of the DNA fragments decreased considerably when they were subsequently purified with a Sepharose CL-4B gel filtration column (Fig. 3). Method III involved extracting the soil DNA using soil plugs. Not only was the amount of humic substances present significantly lower when compared with that extracted by Method II, the size distribution of the fragments was also much greater, with a large portion of the isolated fragments being $100 \mathrm{~kb}$ or more in size. Furthermore, the DNA yields (19.5 $\mu \mathrm{g}$ DNA per gram dry soil) were almost twice those obtained by the soil DNA isolation kit (Fig. 3; Table 1).

\subsection{Construction and analysis of BAC library}

DNA fragments isolated by the new method were employed to construct a BAC library as described in the Materials and methods. By using electroporation, transformation efficiency reached $10^{6} \mathrm{cfu} / \mu \mathrm{g}$ for the large-insert plasmids, with $98 \%$ of the recombinant colonies. A total of 12,000 colonies were isolated for further analysis. Restriction analysis of 120 randomly selected clones (1\% of the library) using NotI found that each clone had an average insert size of $90 \mathrm{~kb}$ (Fig. 4). Consequently, the BAC library included approximately $1.2 \mathrm{Gbp}$ of soil microbial genomic DNA.

\subsection{Phylogenetic analysis of soil DNA library}

To further evaluate the soil BAC library constructed with the newly developed system, a PCR-based rDNA sequence

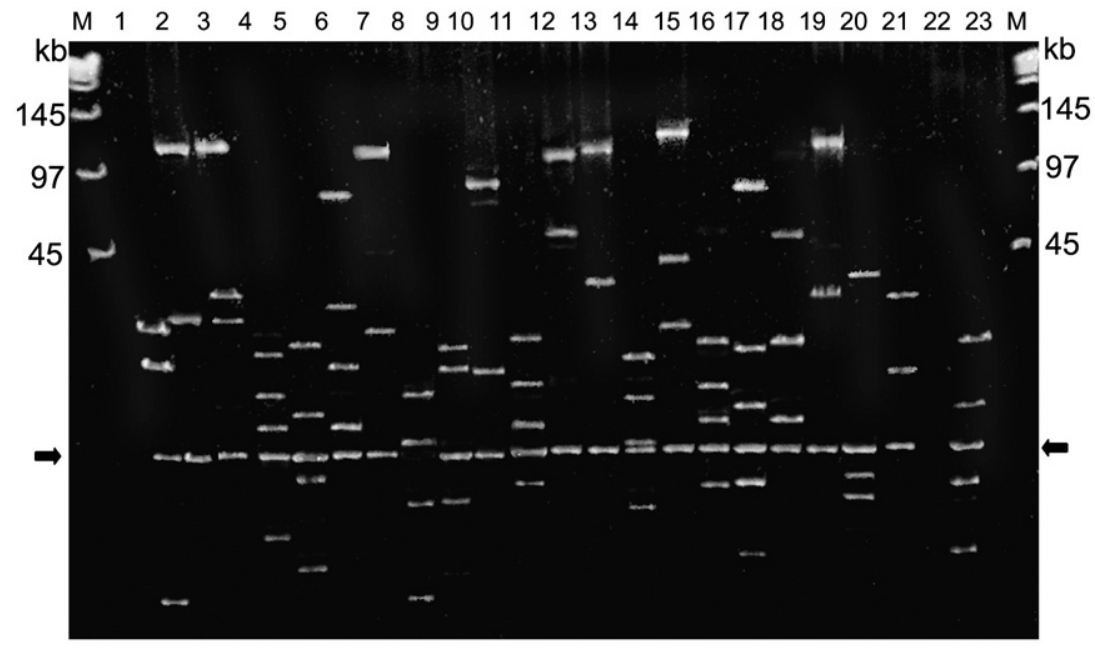

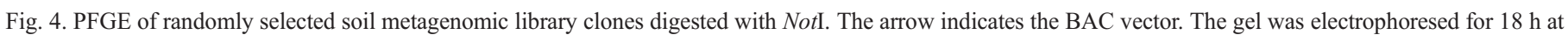
$160 \mathrm{~V}, 8^{\circ} \mathrm{C}$ and with $1-10 \mathrm{~s}$ pulses. Lane M, Lambda Ladder PFG marker. 


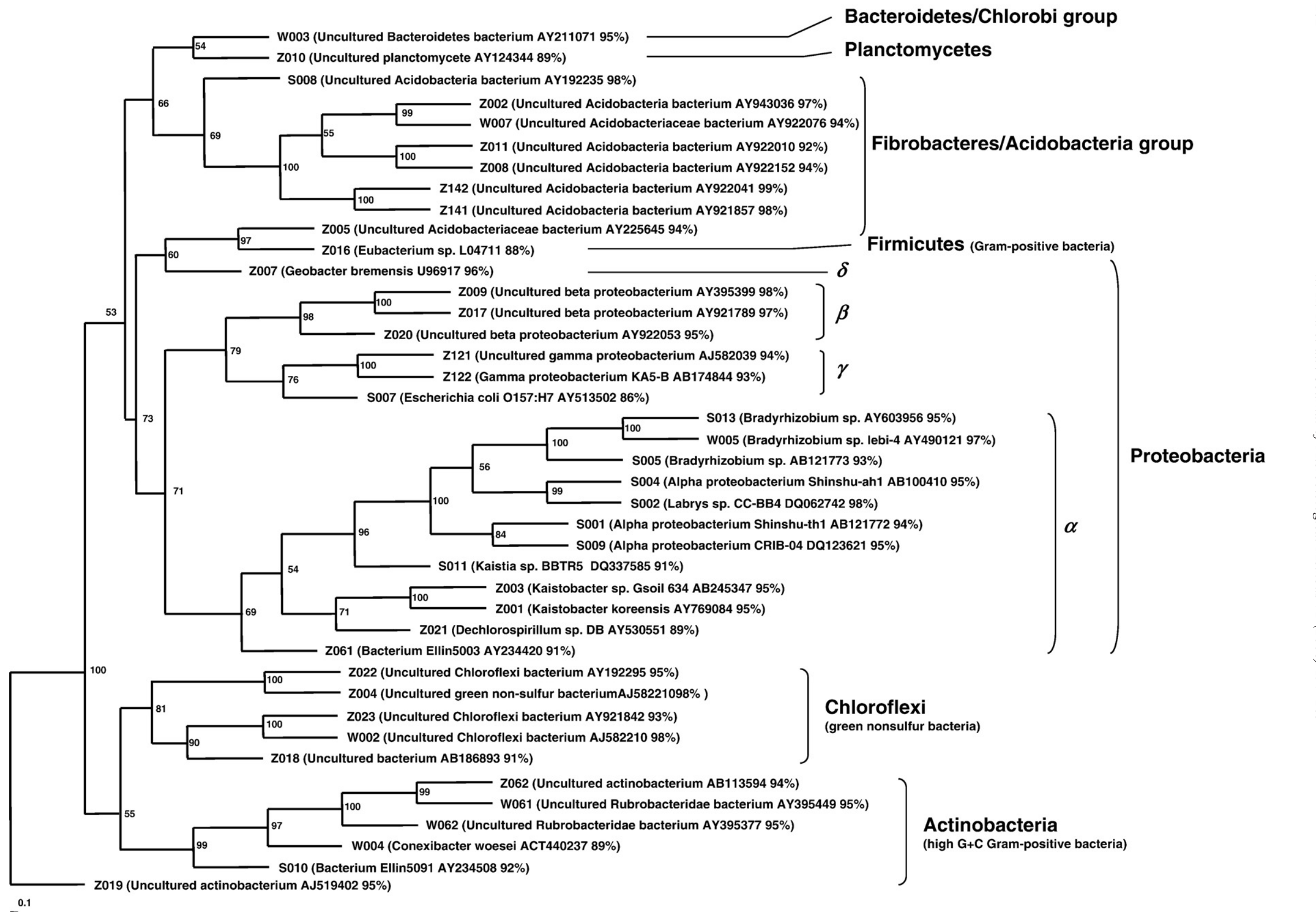

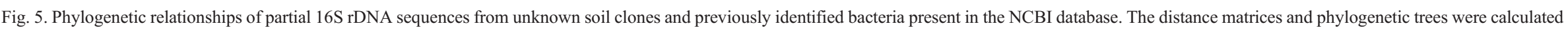

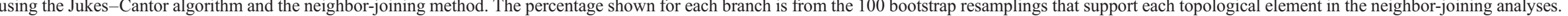

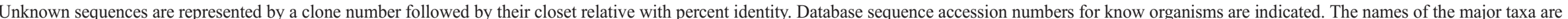
shown in boldface on the right-hand side. The scale bar indicates the substitutions seen per sequence position. 
analysis was performed using Bacteria and Archaea-specific 16S rDNA primers (Hugenholtz and Goebel, 2001). A total of 40 random PCR products, representing partial 16S rRNA gene segments, were amplified from the BAC library pools and sequenced. All of these clones were from the domain Bacteria, i.e., no Archaea sequences were found, and corresponded to more than nine phyla. With a $98.5 \%$ sequence identity cutoff when aligned with BLASTN against the NCBI nucleotide database, it was found that the 40 clones belonged to distinct bacterial ribotypes (Fig. 5), including numerous uncultured microbes from a wide variety of bacterial taxa (Amann et al., 1995; Rossello-Mora and Amann, 2001).

The phylogenetic affiliation of these partial 16S rRNA sequences is illustrated according to their phylogenetic (Fig. 5) and taxonomic distribution (Fig. 6). The results in Fig. 5 agree with the previous finding (Hugenholtz et al., 1998) that $\alpha$ Proteobacteria, Acidobacteria, Actinobacteria and Chloroflexi are broadly seen in soil environments. However, the $16 \mathrm{~S}$ rDNA sequences isolated show that a large percentage of these clones are most similar to uncultured or unclassified bacteria. For example, one sequence clone (Z142) had a 99\% similarity to the uncultured Acidobacteria bacterium AY922041. These results clearly demonstrated that a large portion of the soil organisms, and their metabolisms, still abide in unknown territory. It is also noteworthy that several sequences were from gram-positive bacteria, showing that this method can recover DNA from a widely variety of microbiota, including hard-to-lyse grampositive bacteria.
To further understand the microbe taxonomic distribution, comparison was made with those from similar environments, i.e., agricultural soil and forest soil (Fig. 6). According to the sequences from the three pools, about 12 major phylum groups were seen, with the dominant bacterial species being Proteobacteria and Actinobacteria. All three soil types had similar microbial community profiles, but a pairwise comparison of each with the Pearson correlation coefficient found the microbes present in the orchard soil to be more similar to those found in the agricultural soil $(r=0.97)$ than the forest soil $(r=0.48)$. Furthermore, almost $20 \%$ of the $16 \mathrm{~S}$ rRNA clones identified in this study were unclassified bacteria, which were much higher than the value seen for the forest soil and only slightly more than that for the agricultural soil. The similarities in these profiles suggested that this method is capable of recovering DNA from most of the soil microbiota without the presence of any significant experimental biases.

\section{Discussion}

In Taiwan, orchard soils are commonly exposed to different insecticides and fertilizers in order to increase productivity. This has resulted in a dramatic alteration of the soil structure and nutrition sources, and directly influenced the microbial metabolism and community structure (Borneman et al., 1996). Therefore, creating a soil library to reconstruct microbial genomes will help interpret environmentally-orientated metabolisms and provide insight into the population structure of the

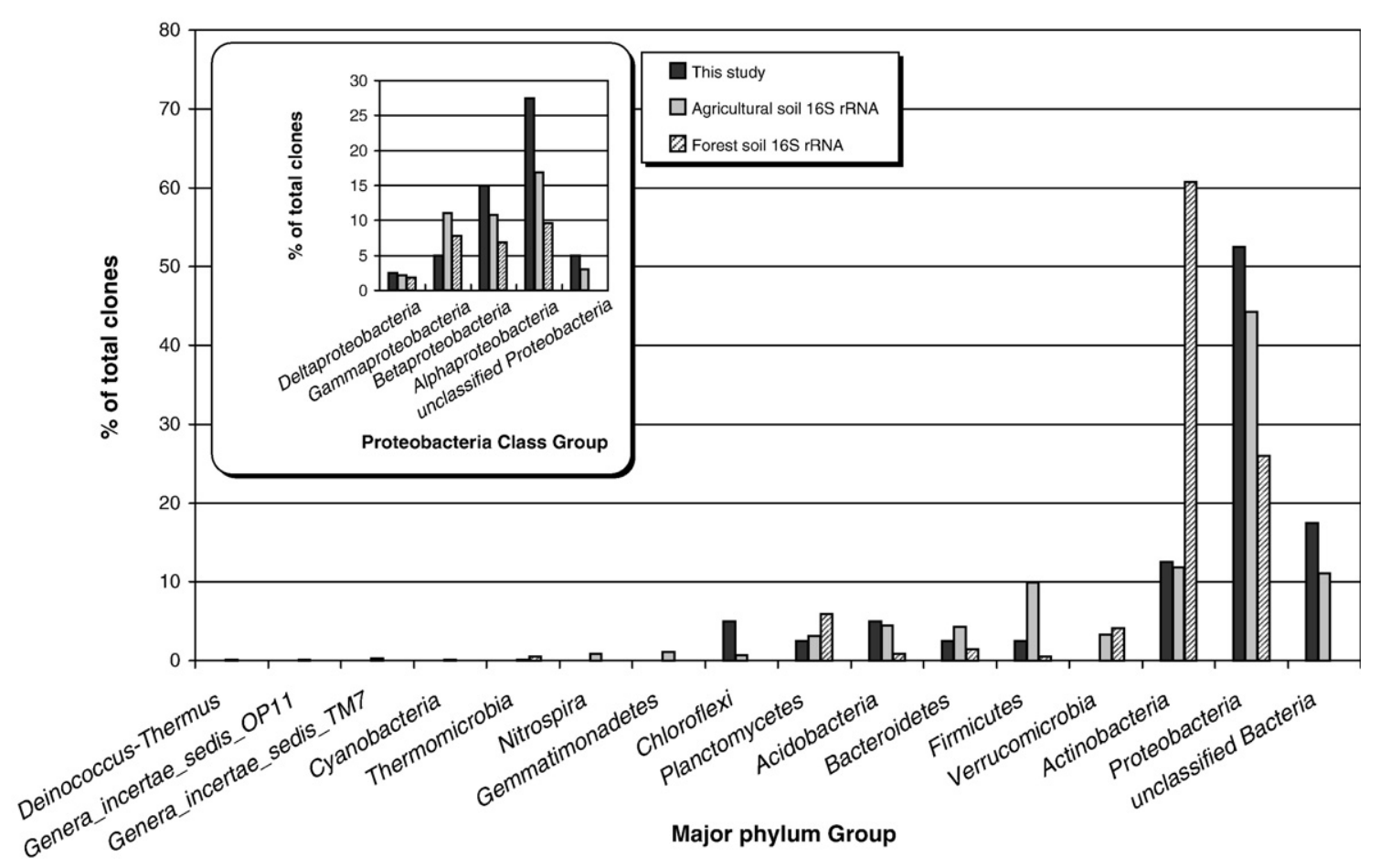

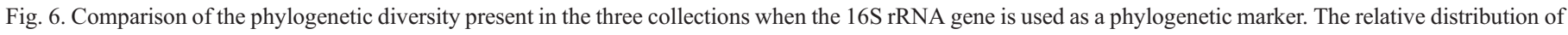

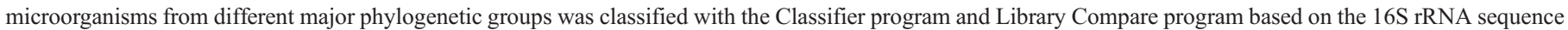

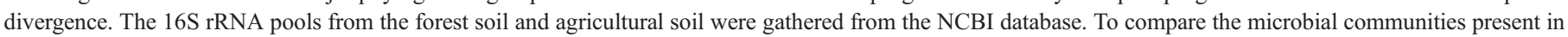

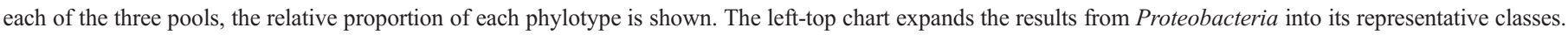


Table 2

Using the Lander-Waterman Model $^{\text {a }}$ to calculate the coverage ratio of a metagenome library for soil microbial communities

\begin{tabular}{|c|c|c|c|c|c|}
\hline $\begin{array}{l}\text { Total sequenced } \\
\text { length }(\mathrm{Gbp})^{\mathrm{b}}\end{array}$ & Coverage $(C)^{\mathrm{c}}$ & $\begin{array}{l}\text { Probability of a base } \\
\text { without sequencing } \\
\left(P_{0}=e^{-C}\right)^{\mathrm{d}}\end{array}$ & $\%$ not sequenced & $\begin{array}{l}\text { The total length } \\
\text { of gap }\left(G e^{-C}\right)^{\mathrm{e}} \\
(\mathrm{Mb})\end{array}$ & $\begin{array}{l}\% \text { sequenced } \\
\left(1-\mathrm{P}_{0}\right)\end{array}$ \\
\hline 1.2 & $0.1 \times$ & 0.90 & 90 & 10,800 & 10 \\
\hline 12 & $1 \times$ & 0.37 & 37 & 4440 & 63 \\
\hline 36 & $3 \times$ & 0.05 & 5 & 100 & 95 \\
\hline 96 & $8 \times$ & 0.0003 & 0.03 & 3.6 & 99.97 \\
\hline
\end{tabular}

a Lander-Waterman Model: Followed by Lander and Waterman, 1988.

b In this study, we assumed $G=12 \mathrm{Gbp}$. (3000 genomes per gram in soil) (Hallam et al., 2004; Torsvik and Ovreas, 2002).

c Coverage $C=\mathrm{LN} / G, \mathrm{LN}$ : number of bases sequenced, $G$ : the length of total genomes.

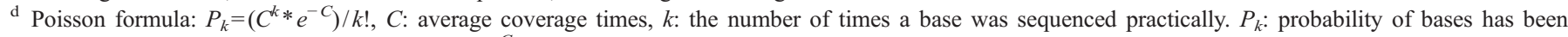
sequenced by $\mathrm{k}$ times. In this Table, $k=0$, so $P_{0}=e^{-C}$.

e The total length of gap $=(\%$ not sequence $) *($ total genomes $)=G e^{-C}$.

microbes present (Hallam et al., 2004; Tyson et al., 2004; Venter et al., 2004; Tringe et al., 2005).

As such, the major goal in this study was to develop a method for retrieving nearly complete genomes from members within soil microbial communities, most of which cannot be isolated by traditional culture methods, and to implement them within a larger-insert soil library. This was achieved in this study through the use of the agarose plugs. During dialysis, most of the soil contaminants, cellular proteins and cellular debris diffuse out of the plugs while the HMW DNA remain trapped within the plug and are subsequently isolated using PFGE (Fig. 1). In a comparison with other methods for isolating DNA from soil samples, it was found that the newly developed direct lysis method yields at least a 10 -fold total DNA recovery more than the cell extraction method (Steffan et al., 1988), separating bacteria from soil particles via a nycodenz gradient (Berry et al., 2003) or suspension in buffer (Quaiser et al., 2002). It was suggested that this new method can be employed to generate a better representative library. Furthermore, HMW DNA was isolated from three different soil types showing that this method is versatile (Fig. 2), but the results also indicated that the characteristics of the soil may have an effect on the final amount of DNA recovered.

Several research groups have reported on the use of shotgun sequencing methods (Hallam et al., 2004; Tyson et al., 2004; Venter et al., 2004; Tringe et al., 2005) to retrieve DNA fragments and construct libraries. However, owing to the huge and complicated microbial community present in the soil, it is difficult to back construct complete genomes using such approaches. This is demonstrated using the Lander-Waterman model (Lander and Waterman, 1988) (Table 2). A minimum of $9.6 * 10^{7}$ clones (with a $8 \times$ coverage, averaging $1 \mathrm{~kb}$ per clone) are required to completely reconstruct the soil microbial genomes where 3000 different species in $1 \mathrm{~g}$ of soil are present (Torsvik and Ovreas, 2002). However, for certain rare genomes $(<1 \%)$ present in the microbiota, at least a $100 \times$ coverage is needed, meaning $1200 \mathrm{Gbp}$ or $1.2 * 10^{9}$ clones. In contrast, large fragments, such as those seen in this study, provide more sequence information for annotation while also improving the accuracy of predicting different genomic characteristics, such as the $G+C$ content, codon usage, and oligo-nucleotide frequencies (Teeling et al., 2004; Chen and Pachter, 2005) and the possibilities of obtaining multiple phylogenetic markers, such as 16S rDNA, RecA/RadA, EF-Tu, EF-G, HSP60/70, and $\mathrm{RpoB} / \mathrm{C}$. The data will further aid in linking each BAC clone to the possible species for reconstruction of the soil microbial genomes.

The phylogenetic analysis of these rDNA sequences provides a straightforward method for exploiting the genetic diversity within the uncultured microbial community. According to the alignment results (Fig. 5), a significant portion of the rDNA sequences corresponded to uncultured and unclassified bacteria, especially in Acidobacteria and Chloroflexi. Acidobacteria is a newly recognized phylum of bacteria and only three species: Acidobacterium capsulatum, Geothrix fermentans and Holophaga foetida have been cultivated thus far (Hugenholtz et al., 1998; Quaiser et al., 2003). Both phyla, Acidobacteria and Chloroflexi, are poorly represented by sequences from cultivated organisms and, consequently, little is known about their general physiological properties. However, our phylogenetic analysis found that large DNA fragments from several strains of these phyla are included in our BAC library and, as such, it should be possible to use the genomic sequences to further evaluate and identify the physiological characteristics of these specific species.

In summary, we have developed a new system using a direct cloning method to carefully extract HMW soil DNA that can be used to construct large-insert metagenome libraries. As seen in the results presented here, the libraries provide unique and highly divergent sequences that can be used as a primary blueprint for reconstructing microbial community genomes and as a platform to discover novel natural products. Furthermore, they can serve as a link between the genetic identities and functions of uncultured microbial communities, helping us to understand the complex networks present within the structure of a microbial community, its environmentally oriented metabolisms and the soil ecosystem as a whole.

\section{Acknowledgments}

This work was supported by funds from NSTPAB NSC grant NSC 92-2317-B-002-010 and 91-2317-B-002-018. We thank Dr. Robert Mitchell for his valuable comments and suggestions on the manuscript; Yi-Fang Tsai and Yi-Han Hsieh for their 
technical assistance of rDNA library analysis; and Chueh-Ling Kuo for her helpful suggestions.

\section{References}

Amann, R.I., Ludwig, W., Schleifer, K.H., 1995. Phylogenetic identification and in situ detection of individual microbial cells without cultivation. Microbiol. Rev. 59, 143-169.

Berry, A.E., Chiocchini, C., Selby, T., Sosio, M., Wellington, E.M., 2003. Isolation of high molecular weight DNA from soil for cloning into BAC vectors. FEMS Microbiol. Lett. 223, 15-20.

Borneman, J., Skroch, P.W., O’Sullivan, K.M., Palus, J.A., Rumjanek, N.G., Jansen, J.L., Nienhuis, J., Triplett, E.W., 1996. Molecular microbial diversity of an agricultural soil in Wisconsin. Appl. Environ. Microbiol. 62, 1935-1943.

Brady, S.F., Chao, C.J., Clardy, J., 2002. New natural product families from an environmental DNA (eDNA) gene cluster. J. Am. Chem. Soc. 124, 9968-9969.

Chen, K., Pachter, L., 2005. Bioinformatics for whole-genome shotgun sequencing of microbial communities. PLoS. Comput. Biol. 1, 106-112.

Courtois, S., Cappellano, C.M., Ball, M., Francou, F.X., Normand, P., Helynck, G., Martinez, A., Kolvek, S.J., Hopke, J., Osburne, M.S., August, P.R., Nalin, R., Guerineau, M., Jeannin, P., Simonet, P., Pernodet, J.L., 2003. Recombinant environmental libraries provide access to microbial diversity for drug discovery from natural products. Appl. Environ. Microbiol. 69, $49-55$.

Daniel, R., 2005. The metagenomics of soil. Nat. Rev. Microbiol. 3, 470-478.

Dobrindt, U., Hochhut, B., Hentschel, U., Hacker, J., 2004. Genomic islands in pathogenic and environmental microorganisms. Nat. Rev. Microbiol. 2, 414-424.

Hallam, S.J., Putnam, N., Preston, C.M., Detter, J.C., Rokhsar, D., Richardson, P.M., DeLong, E.F., 2004. Reverse methanogenesis: testing the hypothesis with environmental genomics. Science 305, 1457-1462.

Henne, A., Daniel, R., Schmitz, R.A., Gottschalk, G., 1999. Construction of environmental DNA libraries in Escherichia coli and screening for the presence of genes conferring utilization of 4-hydroxybutyrate. Appl. Environ. Microbiol. 65, 3901-3907.

Hugenholtz, P., Goebel, B.M., 2001. The polymerase chain reaction as a tool to investigate microbial diversity in environmental sample. In: Rochelle, Paul A. (Ed.), Environmental Molecular Microbiology: Protocols and Applications. Horizon Scientific Press, Wymondham, pp. 31-42.

Hugenholtz, P., Goebel, B.M., Pace, N.R., 1998. Impact of culture-independent studies on the emerging phylogenetic view of bacterial diversity. J. Bacteriol. $180,4765-4774$.

Jackson, C.R., Harper, J.P., Willoughby, D., Roden, E.E., Churchill, P.F., 1997. A simple, efficient method for the separation of humic substances and DNA from environmental samples. Appl. Environ. Microbiol. 63, 4993-4995.

Krsek, M., Wellington, E.M., 1999. Comparison of different methods for the isolation and purification of total community DNA from soil. J. Microbiol. Methods 39, 1-16.

Kuske, C.R., Banton, K.L., Adorada, D.L., Stark, P.C., Hill, K.K., Jackson, P.J., 1998. Small-scale DNA sample preparation method for field PCR detection of microbial cells and spores in soil. Appl. Environ. Microbiol. 64, $2463-2472$.

Lander, E.S., Waterman, M.S., 1988. Genomic mapping by fingerprinting random clones: a mathematical analysis. Genomics 2, 231-239.

Majernik, A., Gottschalk, G., Daniel, R., 2001. Screening of environmental DNA libraries for the presence of genes conferring $\mathrm{Na}(+)(\mathrm{Li}(+)) / \mathrm{H}(+)$ antiporter activity on Escherichia coli: characterization of the recovered genes and the corresponding gene products. J. Bacteriol. 183, 6645-6653.

Osoegawa, K., Woon, P.Y., Zhao, B., Frengen, E., Tateno, M., Catanese, J.J., de Jong, P.J., 1998. An improved approach for construction of bacterial artificial chromosome libraries. Genomics. 52, 1-8.
Quaiser, A., Ochsenreiter, T., Klenk, H.P., Kletzin, A., Treusch, A.H., Meurer, G., Eck, J., Sensen, C.W., Schleper, C., 2002. First insight into the genome of an uncultivated crenarchaeote from soil. Environ. Microbiol. 4, 603-611.

Quaiser, A., Ochsenreiter, T., Lanz, C., Schuster, S.C., Treusch, A.H., Eck, J., Schleper, C., 2003. Acidobacteria form a coherent but highly diverse group within the bacterial domain: evidence from environmental genomics. Mol. Microbiol. 50, 563-575.

Riesenfeld, C.S., Goodman, R.M., Handelsman, J., 2004. Uncultured soil bacteria are a reservoir of new antibiotic resistance genes. Environ. Microbiol. 6, 981-989.

Rondon, M.R., Raffel, S.J., Goodman, R.M., Handelsman, J., 1999. Toward functional genomics in bacteria: analysis of gene expression in Escherichia coli from a bacterial artificial chromosome library of Bacillus cereus. Proc. Natl. Acad. Sci. U S A. 96, 6451-6455.

Rondon, M.R., August, P.R., Bettermann, A.D., Brady, S.F., Grossman, T.H., Liles, M.R., Loiacono, K.A., Lynch, B.A., MacNeil, I.A., Minor, C., Tiong, C.L., Gilman, M., Osburne, M.S., Clardy, J., Handelsman, J., Goodman, R.M., 2000. Cloning the soil metagenome: a strategy for accessing the genetic and functional diversity of uncultured microorganisms. Appl. Environ. Microbiol. 66, 2541-2547.

Rossello-Mora, R., Amann, R., 2001. The species concept for prokaryotes. FEMS Microbiol. Rev. 25, 39-67.

Steffan, R.J., Goksoyr, J., Bej, A.K., Atlas, R.M., 1988. Recovery of DNA from soils and sediments. Appl. Environ. Microbiol. 54, 2908-2915.

Strong, S.J., Ohta, Y., Litman, G.W., Amemiya, C.T., 1997. Marked improvement of PAC and BAC cloning is achieved using electroelution of pulsed-field gel-separated partial digests of genomic DNA. Nucleic Acids Res. 25, 3959-3961.

Teeling, H., Meyerdierks, A., Bauer, M., Amann, R., Glockner, F.O., 2004. Application of tetranucleotide frequencies for the assignment of genomic fragments. Environ. Microbiol. 6, 938-947.

Torsvik, V., Ovreas, L., 2002. Microbial diversity and function in soil: from genes to ecosystems. Curr. Opin. Microbiol. 5, 240-245.

Treusch, A.H., Kletzin, A., Raddatz, G., Ochsenreiter, T., Quaiser, A., Meurer, G., Schuster, S.C., Schleper, C., 2004. Characterization of large-insert DNA libraries from soil for environmental genomic studies of Archaea. Environ. Microbiol. 6, 970-980.

Tringe, S.G., von Mering, C., Kobayashi, A., Salamov, A.A., Chen, K., Chang, H.W., Podar, M., Short, J.M., Mathur, E.J., Detter, J.C., Bork, P., Hugenholtz, P., Rubin, E.M., 2005. Comparative metagenomics of microbial communities. Science 308, 554-557.

Tsai, Y.L., Olson, B.H., 1992. Rapid method for separation of bacterial DNA from humic substances in sediments for polymerase chain reaction. Appl. Environ. Microbiol. 58, 2292-2295.

Tyson, G.W., Chapman, J., Hugenholtz, P., Allen, E.E., Ram, R.J., Richardson, P.M., Solovyev, V.V., Rubin, E.M., Rokhsar, D.S., Banfield, J.F., 2004. Community structure and metabolism through reconstruction of microbial genomes from the environment. Nature 428, 37-43.

Venter, J.C., Remington, K., Heidelberg, J.F., Halpern, A.L., Rusch, D., Eisen, J.A., Wu, D., Paulsen, I., Nelson, K.E., Nelson, W., Fouts, D.E., Levy, S., Knap, A.H., Lomas, M.W., Nealson, K., White, O., Peterson, J., Hoffman, J., Parsons, R., Baden-Tillson, H., Pfannkoch, C., Rogers, Y.H., Smith, H.O., 2004. Environmental genome shotgun sequencing of the Sargasso Sea. Science 304, 66-74.

Voget, S., Leggewie, C., Uesbeck, A., Raasch, C., Jaeger, K.E., Streit, W.R., 2003. Prospecting for novel biocatalysts in a soil metagenome. Appl. Environ. Microbiol. 69, 6235-6242.

Zhou, J., Bruns, M.A., Tiedje, J.M., 1996. DNA recovery from soils of diverse composition. Appl. Environ. Microbiol. 62, 316-322.

Zimmer, R., Verrinder Gibbins, A.M., 1997. Construction and characterization of a large-fragment chicken bacterial artificial chromosome library. Genomics 42, 21 